\section{Hematological profile of sickle cell disease from South Gujarat, India}

Sanjeev Shyam Rao, Jagdish Prasad Goyal, S.V. Raghunath, Vijay B. Shah

Department of Pediatrics, Govt Medical College, Surat, Gujarat, India

\begin{abstract}
The aim of this study was to determine hematological profile of sickle cell disease (SCD) from Surat, South Gujarat, India. This prospective cross-sectional study was conducted in the Department of Pediatrics and Sickle Cell Anemia Laboratory, Faculty of Pathology, Government Medical College, Surat, India, between July 2009 and December 2010. Patients included in this study were in their steady state for a long period of time without any symptoms related to SCD or other diseases which could affect the hematological parameters. Venous blood of all patients was collected in ethylenediaminetetraacetic acid and hematological indices were measured. Thirty-three subjects homozygous in all were studied for their hematological parameters for sickle cell anemia. Moderate to severe anemia, low mean cell volume and high foetal hemoglobin dominate the hematological profile of SCD children.
\end{abstract}

\section{Introduction}

The sickle cell disease (SCD) is a very common single gene disorder; $50 \%$ of world population affected by SCD resides in India. The average frequency of SCD gene ranges between $22-44 \%$. High prevalence of sickle gene has been demonstrated in various tribal communities of Gujarat, India. ${ }^{1}$

Hematological profile of SCD is extremely variable. There is paucity of data on hematological profile of SCD from India. Therefore this study was undertaken to determine hematological profile of SCD from Surat, South Gujarat, India, catering tribal patients from Surat, Valsad and Dang districts. ${ }^{2}$

\section{Materials and Methods}

This prospective cross-sectional study was conducted in the Department of Pediatrics and Sickle Cell Anemia Laboratory, Department of Pathology, Government Medical College, Surat for a period of July 2009 to December 2010. Most of patients were from tribal background and lower socioeconomic status. Before conducting the study, permission was obtained from the Institutional Ethical Clearance Committee. Patients included in this study were in their steady state for a long period of time without any symptoms related to SCD or other diseases which could affect the hematological parameters. Subjects who have been transfused in the last 3 months were excluded from the study.

Detail history was elicited to obtain information on all SCD related symptoms. Most of the blood samples are collected during Outpatient Department visit. Venous blood of all patients was collected in ethylenediaminetetraacetic acid (EDTA) and hematological indices were measured on KX 21 Sysmex auto analyzer. Quantification of foetal hemoglobin (HbF) was done on Bio-Rad variant system using high performance liquid chromatography (HPLC). Hematological profile was compared with other studies.

\section{Statistical analysis}

Data was recorded on a pre-designed Performa and managed on Excel spread sheet. All the entries were double checked for any possible key-board error. Statistical analysis was done by unpaired t- test with the help of Epi info 6 (CDC, Atlanta). In this study $\mathrm{P}<0.05$ was considered as statistically significant.

\section{Results}

A total of 33 subjects homozygous (SS) (mean age $9.6 \pm 3.2$ years) for sickle cell anemia was studied for their hematological parameters. Out of the total SS subjects, 24 were males and 9 were females. Males outnumbered females sex ratio: 2.6. Age ranged from 5 years to 15 years. Mean (SD) age of male was 9.5 (3.19) years whereas SD age of female was 9.89 (3.89) years. Hematological profile of study subjects are shown in Table 1.

\section{Discussion}

There were more male as compared to females in the present study, which may be due to the fact that male child gets more attention as compared to female child. Total hemoglobin (Hb) is low in SCD patient more so in females as compared to males although this is not statistically significant $(\mathrm{P}>0.05)$ This may be due to hemolysis, blood loss due to hematuria, ${ }^{3}$ repeated infections, and nutritional deficiencies because of low socio-economic status. According to National Family Health
Correspondence: Jagdish Prasad Goyal, Department of Pediatrics, P.D.U.Medical College, Rajkot, Gujarat, India.

Tel. +919998521520

E-mail: jpgoyal@rediffmail.com

Key words: hematological profile, sickle cell disease, children, south gujarat.

Acknowledgement: Dr B.M. Jha, Associate Professor\& In-charge Sickle Cell Anemia Laboratory for performing HPLC of our patients.

Received for publication: 23 December 2011.

Revision received: 18 March 2012.

Accepted for publication: 14 April 2012.

This work is licensed under a Creative Commons Attribution NonCommercial 3.0 License (CC BYNC 3.0).

(C) Copyright S.S. Rao et al., 2012

Licensee PAGEPress, Italy

Hematology Reports 2012; 4:e8

doi:10.4081/hr.2012.e8

survey (NFHS-3), anemia is common in India among the schedule cast and tribes and among the children with low socio-economic status. ${ }^{4,5}$ Total red cell count count, mean cell hemoglobin (MCH) and mean cell hemoglobin concentration (MCHC) are low in our study which is comparable to other studies. ${ }^{6,7}$ Mean cell volume (MCV) is low in our study as compared to other study. ${ }^{8,9}$ Usually MCV is high in SCD patients because of the increasing need of erythropoiesis due to chronic hemolysis leading to macrocytosis. It would also be related to a folic acid deficiency. Low MCV in our study as compared to other study may be due to co-existing iron deficiency anemia and other unknown factors such as $\alpha$-thalassemia which is frequent and often associated to SCD. ${ }^{9-11}$ Mean HbF level was high and no sex related difference in $\mathrm{HbF}$ values was observed in present study $(\mathrm{P}>0.05)$. Although $\mathrm{HbF}$ value (12. 3\%) was higher than in African study yet it was low as compared to Indian studies. ${ }^{12-14}$ Indian patients usually carry Arab-Indian haplotype, which is associated with high $\mathrm{HbF}$ levels, which fails to copolymerize with abnormal hemoglobin $(\mathrm{HbS}) .{ }^{15}$ The difference in level of different studies may be due to coinheritance trait of $\alpha$ or $\beta$ thalassemia gene or a strong genetic component and clinical status of the patients. ${ }^{16-19}$

\section{Conclusions}

We conclude that moderate to severe anemia, low MCV and high HbF dominate the hematological profile of South Gujarat SCD children. 
Table 1. Hematological comparison between male and female sickle cell patients $(n=33)$.

\begin{tabular}{lccrc} 
& $\begin{array}{c}\text { Male }(\mathrm{n}=24) \\
\text { Mean } \pm \text { SD }\end{array}$ & $\begin{array}{c}\text { Female }(\mathrm{n}=9) \\
\text { Mean } \pm \text { SD }\end{array}$ & $\begin{array}{c}\text { Total } \\
\text { Mean } \pm \text { SD }\end{array}$ & P \\
$\mathrm{Hb}(\mathrm{g} / \mathrm{dL})$ & $7.86 \pm 1.87$ & $7.41 \pm 1.92$ & $7.73 \pm 1.86$ & 0.55 \\
$\mathrm{HCT}(\mathrm{gm} / \mathrm{dL})$ & $27.35 \pm 3.84$ & $26.39 \pm 7.69$ & $27.09 \pm 5.05$ & 0.63 \\
\hline $\mathrm{RBC}\left(\mathrm{mill} / \mathrm{mm}^{3}\right)$ & $3.61 \pm 0.96$ & $2.95 \pm 0.96$ & $3.43 \pm 0.99$ & 0.09 \\
$\mathrm{MCV}(\mathrm{fL})$ & $76.00 \pm 5.67$ & $75.67 \pm 5.87$ & $75.90 \pm 5.63$ & 0.88 \\
\hline $\mathrm{MCH}(\mathrm{pg})$ & $26.61 \pm 2.21$ & $25.99 \pm 1.62$ & $26.30 \pm 2.12$ & 0.45 \\
$\mathrm{MCHC}(\mathrm{g} / \mathrm{dL})$ & $32.84 \pm 1.04$ & $32.94 \pm 0.83$ & $32.86 \pm 0.97$ & 0.76 \\
\hline $\mathrm{HbF}(\%)$ & $12.56 \pm 7.60$ & $11.97 \pm 6.68$ & $12.2 \pm 7.1$ & 0.83 \\
$\mathrm{WBC}(\times 103 \mu \mathrm{L})$ & $10.6 \pm 6.3$ & $14.3 \pm 5.9$ & $11.6 \pm 6.4$ & 0.14
\end{tabular}

$\mathrm{Hb}$, hemoglobin; HCT, hematocrit; RBC, red cell count; MCV, mean cell volume; MCH, mean cell hemoglobin; MCHC, mean cell hemoglobin concentration; HbF, foetal hemoglobin; WBC, white blood cells.

\section{References}

1. Vasava B, Chudasama R, Godara N, et al. Prevalence of sickle cell disease in tribal adolescents of the South Gujarat region, India. Available from: http://www. ispub.com:80/ journal/the-internet-journal-of-tropical-medicine/volume-6-number-1/prevalence-of-sickle-cell-disease-intribal-adolescents-of-the-south-gujaratregion-india.html

2. National Rural Health Mission Program Implementation Plan 2011-12. Available from: http://pipnrhmmohfw.nic.in/ index files/non_high_focus_large/gujarat/05.\%2 0Chapter\%204/4.D\%20DCP/10.pdf

3. Wong WY, Elliott-Mills D, Powars D. Renal failure in sickle cell anemia. Hematol Oncol Clin North Am 1996;10:1321-31.

4. National Family Health Survey-3: Summary of findings. Available from: http://www.nfhsindia.org/nfhs3.html Accessed on May 2, 2012.
5. Kar BC, Satapathy RK, Kulozik M, et al. Sickle cell disease in Orissa state, India. Lancet 1986; 22:1198-201.

6. Roy B, Dey B, Balgir RS, et al. Identification of sickle cell homozygotes using haematological parameters. J Indian Anthrop Soc 1996;31:191-9.

7. Tshilolo L, Wembonyama S, Summa V, Avvisati G. [Hemogram findings in Congolese children with sickle cell disease in remission]. Med Trop (Mars) 2010; 70:459-63. [Article in French]

8. Kaur M, Das GP, Verma IC. Sickle cell trait and disease among tribal communities in Orissa, Madhya Pradesh and Kerala. Indian J Med Res 1997;105:111-6.

9. Mohanty D, Mukherjee MB, Colah RB, et al. Iron deficiency anaemia in sickle cell disorders in India. Indian J Med Res 2008; 127:366-9.

10. Figueiredo MS, Kerbauy J, Goncalves MS, et al. Effect of $\alpha$-thalassemia and $\beta$-globingene cluster haplotypes on the hematological and clinical features of sickle cell anemia in Brazil. Am J Haematol 1996;53: 72-7.

11. Falusi AG, OLatunji PO. Effects of alpha thalassemia and haemoglobin $\mathrm{F}(\mathrm{HbF})$ level on the clinical severity of sickle cell anaemia. Eur J Haematol 1994;52:13-5.

12. Hayes RJ, Beckford M, Grandison Y, et al. The haematology of steady state homozygous sickle cell disease: frequency distributions, variation with age and sex, longitudinal observations. Br J Haematol 1985; 59:369-82.

13. Shrikhande AV, Dani AA, Tijare JR, Agrawal AK. Hematological profile of sickle cell disease in central India. Indian $\mathrm{J}$ Hematol Blood Transfus 2007;23:92-8.

14. Khan Y, Thakur AS, Mehta R, et al. Hematological profile of sickle cell disease: A hospital based at CIMS, Bilaspur, Chhattishgarh. Int J Appl Biol Pharm Technol 2010;1:717-721.

15. Mukherjee MB, Lu CY, Ducrocq R, et al. Effect of alpha-thalassemia on sickle-cell anemia linked to the Arab-Indian haplotype in India. Am J Hematol 1997;55:104-9.

16. Thein SL, Menzel S. Discovering the genetics underlying fœtal haemoglobin production in adults. Br J Haematol 2009; 145:455-67.

17. Akinsheye I, Alsultan A, Solovieff N, et al. Fetal hemoglobin in Sickle Cell Anemia. Blood 2011;118:19-27.

18. Mouélé R, Galaeteros F, Fengold 0 . Hemoglobin F (HbF) levels in sickle cell patients homozygous for the Bantu haplotype. Eur J Haemotol 1999;63:136-7.

19. Nagel RL, Rao SK, Dunda-Belhodja 0, et al. The hematologic characteristics of Sickle Cell Anemia bearing the Bantu haplotype: the relationship between $\mathrm{G} \lambda$ and $\mathrm{HbF}$ level. Blood 1987;69:1026-30. 